\title{
The Virgin Mary and the Sacred Body The Ideology of Gender Embodied in the Cistercian Church
}

\author{
Eva-Marie Göransson
}

\begin{abstract}
The Cistercians' choice of dedicating the entire order to the Virgin Mary is of vital importance to an analysis of the ideology embodied in their specific architecture. Mary, the "debodied" sacred body, the "dewomanized" woman, was the very essence of the Cistercian way of life. The aim of this paper is not to make an overview of the Cistercian order but to show how ideology - here understood as a mental dimension of a material practice - can be seen in material culture and, in this case, identified in written sources.
\end{abstract}

Eva-Marie Göransson, Department of Archaeology, Stockholm University, S-10691 Stockholm, Sweden.

\section{THEORETICAL AND METHODO- LOGICAL OUTLINES}

Is archaeology really capable of digging up mentality? This article should be seen as an attempt to answer yes to that question, and hopefully to give an example of how this actually can be done. Traditionally, archaeology has shown an overwhelming love for the practical and "material" aspects of the lives of prehistoric/historic women and men. Economy, subsistence patterns and trade have been seen as reflected in the archaeological record, in contrast to beliefs, attitudes, moral commitments etc. The latter have been relegated by Clarke to the "Black Box" (Clarke 1968:58pp). This is an illusion. The fear of coping with metaphysics, mentality, and the "non-material" aspects of life can be seen as an unconscious clinging to the Binfordian heritage, even though we believe we have abandoned him. The living prehistoric society is just as present/absent whether we ask questions concerning, for instance, the Scandinavian state formation process or the attitu- des to death among Viking Age women!

Feminist archaeology is on the rise and must be seen as a healthy challenge to all the established kinds of archaeological concepts that exist today. The starting point is considered by many to be Conkey and Spector's article "Archaeology and the Study of Gender" from 1984, which is heavily influenced by neo-Marxist anthropology. I would like to argue that most of the feminist archaeology today is still deeply rooted in the anthropology of the 1970s and the traditional Marxist view that ideology (here, gender patterning) is one-way determined by production. This leads to a preoccupation with division of labour, housekeeping, family life, etc. Of course these are important problems, but there must be room for other objects of study as well, especially those which have been deported by Marxists to the untouchable superstructure.

A primary condition for this study is, of course, that one can actually find ideology in material culture. I believe this is possible. Ideology is fixed and embodied in the object, 
in its design and relation to other objects, in the space that the object creates in itself and in its spatial relation to other objects. The problem is to identify the ideology in question, to give it a name in order to describe its role in the political and social strategies in which it played a part. In this article the problem is overcome, or rather bypassed (!), by choosing an object whose ideology is given a name in written sources. The question of how to identify ideology (or any other kind of meaning) on the basis of material culture alone is immensely important, but unfortunately too complex for further discussion here.

In this paper I will concentrate on the ideology of gender and how it actually was attached to, and negotiated through, material culture. As the object of study I have chosen the architecture of the Cistercian church. Concerning the method of treating the actual material, I have been inspired by Roberta Gilchrist's spatial analysis of gender domains in medieval English nunneries (churches not included) (Gilchrist 1988). The ritual aspect of the analysis is influenced by Staale SindingLarsen's work "Iconography and Ritual" (1984), where the iconography of the Roman Catholic church is seen as a practice functioning in a liturgical, theological and historical context, and not as a passive reflection of the Christian concepts (Sinding-Larsen 1988:29). As a means of identifying the ideology in question, I have made use of written sources treated by other researchers.

As a first theoretical point of departure, I draw on Michel Foucault's theory of the body, where the latter is seen as a historically and culturally specific entity on which power relations are exercised (Foucault 1979:26,136). Lois McNay has developed Foucault's theory of the body in a fruitful way and criticised it from a feminist point of view (McNay 1992). She emphasizes the notion of the body as central for feminist analysis, since it is upon the biological difference between female and male bodies that the edifice of gender is built and legitimized (McNay 1992:17). McNay also shows that a theory of the body does not have to exclude the acting subject (as Foucault does it) (McNay 1992:47). My second point of theoretical departure is Janet Wolffs development of the Marxist view of art in society. In traditional Marxism, art is looked upon as a legitimizing reflection of production, situated in the superstructure, which lacks a creative power of its own. Wolff, inspired by Louis Althusser among others, rejects this reductionist view and argues that art could be seen as an embodied ideology, socially produced and historically situated; and in relation to the social and historical context it may contain a formative power of its own (Wolff 1982). Concerning the mental-material perspective in this article, I have been influenced by Maurice Godelier's work "The Mental and the Material" (1986).

\section{THE CULT OF THE VIRGIN MARY AND THE CHRISTIAN VIEW OF WOMEN}

The cult of the Virgin Mary arose in the fifth century A.D. (Warner 1985:291), about a hundred years after the Roman emperor Constantine together with his mother St. Helena, converted to Christianity. From being a religion of slaves, women, and persons excluded from society, Christianity eventually became the official religion of the empire. This brought forth an entirely new function: to unite and organize the disrupted Roman empire. Christianity took over not only the imperial symbols of power, but it also exchanged its previous striving for social equality for the hierarchic social structure and patriarchal ideals of the Roman empire (Rey-Henningsen 1986:17). At the Council of Efesos in 431 A.D. the dogma concerning Mary's motherhood of God, and thus her virginity, was established, and upon this all other dogmas related to Mary were founded (Johansson 1987:73). The empress Eudocia (408-50 A.D.) was an enthusiastic amateur archaeologist, 
and in her tradition several relic-finds were made. The clothes of the Virgin began to appear around 450 A.D. followed by her house and her grave in the following centuries. Especially the clothes of the Virgin were considered important, impregnated as they were with her holiness since they had been in direct communication with her "pure" body (Warner 1985:291pp).

Although in the Eastern Church the Virgin Mary had been worshipped since the earliest days, the cult of the Virgin did not show up in the West until the end of the tenth century. Marisa Rey-Henningsen argues that the theology associated with Mary was a consequence of a polemic between the Roman Catholic church and the non-Christian Romans, Jews and Muslims. According to her, it was because the dogma of virginity was seen as the very proof of Christ being the son of God that the virginity of Mary was fanatically defended and focused, and not because of a clerical wish of submitting women (ReyHenningsen 1986:22). Here I think Rey-Henningsen confuses the conscious and unconscious intentions of the Church with the conscious and unconscious effects on people. The acting subject is always split between the conscious and unsconscious (Kristeva 1989:6), and what one actually believes is the cause of one's action is often something quite different (as well).

It was the Cluny Congregation that in the end of the tenth century initiated the celebration of Mary in the Western Church as the "Mother of Mercy" - iconographically intrepreted as the "Cloak Madonna" (Kraus 1982:84). In the eleventh century the custom of worshipping images of the Virgin Mary was spreading enourmously in the Pyrenées, and it was brought by missionaries to other parts of Europe, especially to Spain which had been recently reconquered from the Muslims (Rey-Henningsen 1986:25). In the twelfth century the cult of the Virgin gained in popularity, simultaneously with the Gregorian reformist movement (1050-1215) (Le
Goff 1988:102). The latter can be seen as a reaction to the increasing clerical concentration of power and wealth, in embarrassing contrast to the ideal of asceticism in St. Benedict's monastic rules from the fifth century, and of course to the message given in the Gospel. The Gregorian movement emphasized the Benedictine ideals and the wish for a separation between the Church and the wordly power, but central was also the demand for clerical celibacy, prohibition of marriage and concubinage, which previously had been widely practiced (Kraus 1982:82-3). According to Jaques Le Goff, the barrier clergy-laity in this way mainly became a sexual one. It also brought forth an annihilation of the "gay culture" previously flourishing "in the shadow of the Church, if not in its very bosom" (Le Goff 1988:102).

The rule of celibacy did not improve the attitudes towards women, even though it could have been expected. On the contrary, women were now seen as synonymous with male $\sin$. They alone bore the responsibility of alienating men from God. The impurity of women and their carnal, material nature was, however, not a new idea. The Aristotelian view of women and human conception (Fig.1) attracted Christian theologists like Augustine as early as the beginning of the fifth century, thereby linking the concept of original sin to sexuality (Le Goff 1988:97). It reached enormous popularity 6-700 years later through the Arabic translations available via the Crusades (Ambjörnsson \& Elzinga 1987:176pp).

If women "by nature" became polluted and represented male $\sin$, what, then, was more natural than to centre the religious devotion towards a truly "pure" woman, a woman who strangely enough was mother and virgin at the same time - an absolute biological impossibility, who even after giving birth kept her maidenhood "intact". Mary Daly has stressed the implication for womens' self destruction in having an identification object that was in herself empty as an egg- 


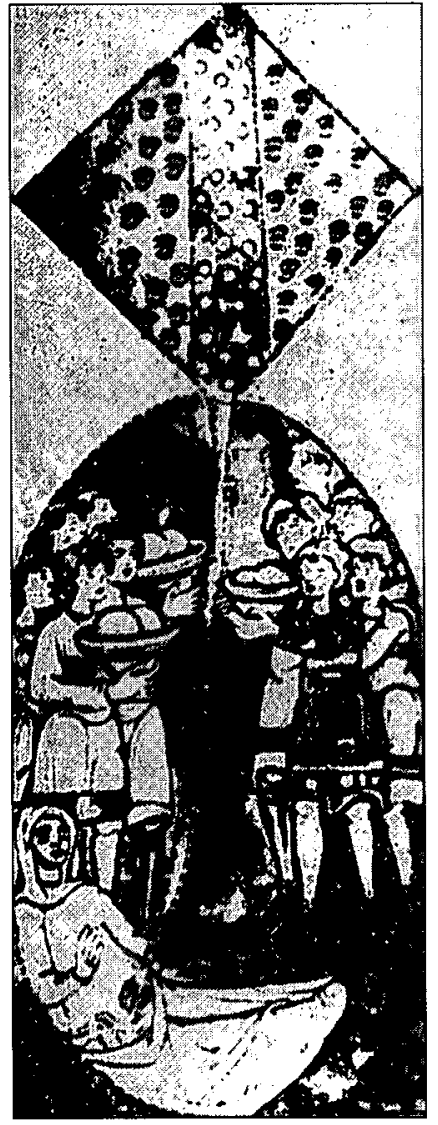

Fig. 1. The Aristotelian view of human conception. Human life is created when the female slow matter is activated by the male semen, like cheese is made from milk. In this illustration from the thirteenth century, ten men extend out large bowls with cheese while the divine semen is descending in the womb of a woman who lies on the ground at their feet (Ambjörnsson \& Elzinga 1987:177).

shell, raped by an angel, and remained a virgin after giving birth to the "fruit" of this abuse (Daly 1979, 1985). Here we have a true example of politics exercised on the human body in the Foucaultian sense. The notion of female pollution was rubbed into every pore by the religious rituals from birth to death.
THE CISTERCIAN ORDER AND ITS ARCHITECTURE

The Cistercian order was founded 1098 in Citaux, France, as an ascetic reformist movement against the agglomeration of power in the monastic system and in the Church (most obviously expressed in the so called Cluny Congregation) (Curman 1912:12-3 and Holmström \& Tollin 1990:302). It is also of utter importance to bear in mind the heretic movement and inquisition in Languedoc and the north of Italy when one considers the intensity of the Cistercians' striving for purity. In fact, Citaux was directly involved in the combat against the heretics in "Le Midi" (Duby 1980:153, 159pp).

The Cistercian abbeys, according to the rules, were supposed to be situated in an uninhabited area and their members were expected to support themselves by manual work on donated land (Holmström \& Tollin 1990:302). The nuns and monks, the majority of whom were recruited from the nobility, did, in fact, none of this but instead were provided for by conversae/conversi from the lower social strata (Curman 1912:17pp). Among these were also the workers who built the characteristic Cistercian churches and abbeys (Curman 1912:21). This was contradictory to the Benedictine rules which stressed social equality among the monks (Curman 1912:21), and in my view it can also be seen as a preservation of the ultimate social hierarchy - slavery - a heritage of the Roman cultural chauvinism. The abbeys grew to veritable industries, which, contrary to their rules, got enormous estates, were engaged in agricultural production for sale, iron production, brick production, etc. (see f.ex. Holmström \& Tollin 1990).

The design of the very building- the abbey - can be seen as a condition for the observance of the monastic rules, and is thus a determining factor in the explosive expansion of the Cistercian order in the whole of Europe during the twelfth and thirteenth centuries. A spatial analysis of the Cistercian abbey 
clearly shows that human life is "boxed up" within the walls (Fig.2). Each desired activity in daily life is given a specific room in the building, and the attitudes towards the different activities in question can be seen in the spatial relations of the rooms. A very strict social hierarchy is conducted within the rooms and spaces intended for the different sexes and social categories. The department of the conversae/conversi, for example, is totally separated from that of the nuns/monks; and the most extreme regulations could be observed in the design of the church (see below). This was, however, nothing new for the Cistercian architecture, but a rather preserved antique ideology centered around a wealthy patriarch (father) where wife, children, concubines and slaves were placed in specific rooms and spaces. The Cistercian abbey is, in fact, an almost exact copy of the classical Roman villa (Härdelin 1987:48), with separate areas for the different social categories living in/visiting the building. Through daily life in the villa - daily meals, feasts, childbirths, deaths, sexual activity, etc. - the Roman social caste system, which was based on slavery, was ritualised and thereby reproduced. The architecture made this social structure possible.

The Cistercian architecture, like the villa, had a separate department for the servants (conversae/conversi) whose work made the contemplative life of the nuns/monks possible. The main difference between the Cistercian abbey and the Roman villa is, of course, the church, even if this too can be seen as having a corresponding functional forerunner in the Roman shrine located at the entrance of the villa, and a corresponding architectural forerunner in the Roman basilica (a nonreligious public hall). In the abbey, the sacred space has taken on huge proportions and dominates the whole building. The church and the rituals exercised in it was the point around which life was centered. About seven or eight hours a day could be spent in religious activity in the church, according to

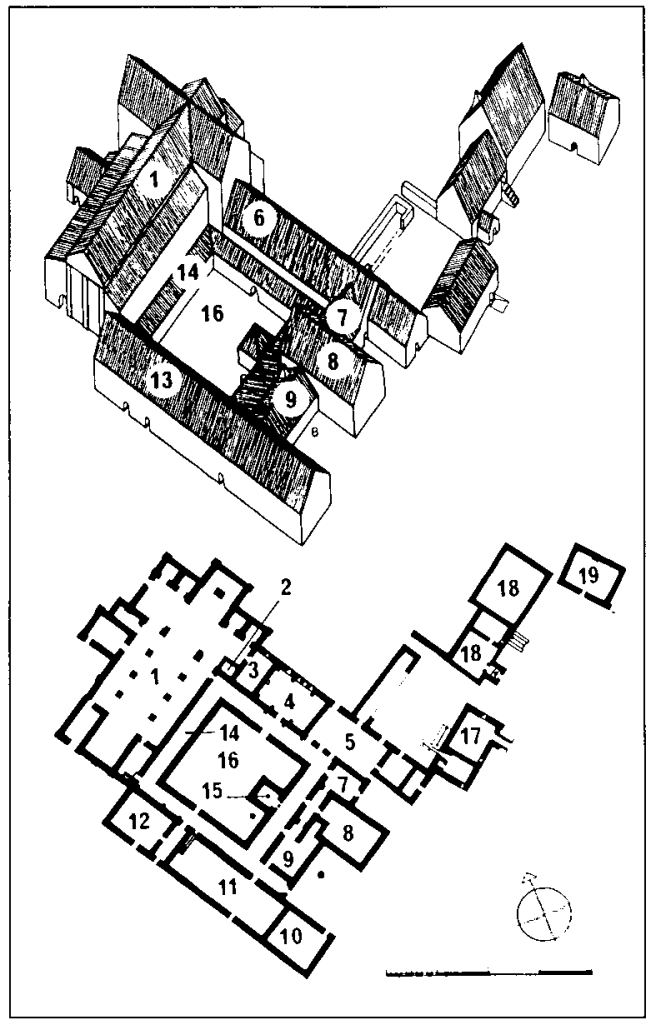

Fig. 2. Reconstruction and plan of Alvastra monastery (Härdelin 1987:49).
1 Church

2 Library (armarium)

3 Sacristy

4 Chapter house

5 Workroom (auditorium)

6 Dormitory

7 Calefactory

8 Dining room (refectorium) 15 Laundry (lavatorium)

9 Kitchen

10 Workroom of the conversi 17 Dwelling of the Abbot

18 Gitest house?

19 Cottage hospital?

\section{Alf Härdelin (Härdelin 1987:54).}

The Cistercian architecture was strictly regulated, and its outlines were prescribed in the "Consuetudines Ordinis Cisterciensis" together with rules for all aspects of a monastic life led in a Cistercian abbey (Curman 
1912:36). Decorations of any kind were prohibited, and in every detail the aim for simplicity was present (Curman p.17-8). That the rules were observed was controlled through a special kind of supervision apparatus called "Capitulum Generalis", whereby the abbots of the monasteries were annually in direct contact with the mother abbey in Citaux (Curman 1912:15-6). The nunneries were a partly different matter, discussed in an article by Sally Thompson (1989). Hoards of women throughout Europe gathered in order to live according to the rules of the Cistercian order. This was considered a problem. The nunneries were not welcome at the annual assemblies in Citaux, and periodically they were not allowed to be established at all. In 1220 the foundation of Cistercian nunneries was restricted and in 1228 altogether prohibited (Curman 1912:29). As a result of this, the Cistercian nunneries often took over a previous local parish church (Curman 1912:29-

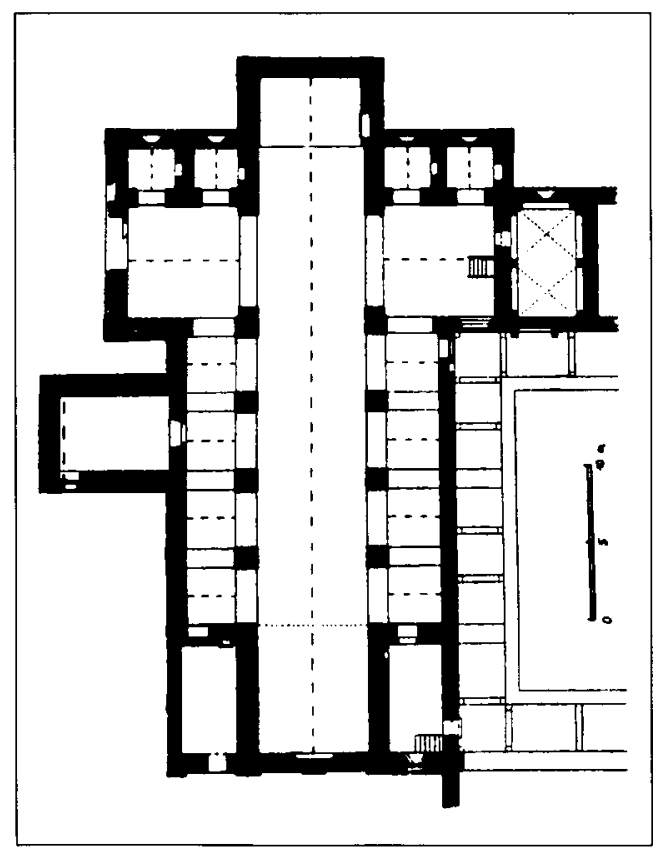

Fig. 3. The church plan of Alvastra monastery (Kennerstedt 1990:121).
30), and in my opinion they must have been more dependent on their donators than their male counterparts, which had a strong support in the Capitulum Generalis Institution. The misogyny towards nuns is remarkable considering the love and devotion the Cistercian order held for the Virgin Mary. The entire order was, in fact, dedicated to her (Warner 1985:131).

\section{ANALYSIS OF THE HIERARCHICAL SYMBOLISM AND GENDER IDEOLOGY OF THE CISTERCIAN CHURCH}

The Cistercian church of the twelfth and thirteenth centuries is of a type called "crux capitata" that was quite common during this time. Its specifically Cistercian features were the outline of the chancel, especially the sanctuary where the main altar was situated, an unusually elongated main nave, and a small hall in the western part of the church (Curman 1912:25-26). Typical for the Cistercian church was also the absence of a tower, the triple-nave, a transept in the east, a square chancel, the west-east orientation of the arches in the vaults of the main nave, and the north-south orientation of the arches in the aisles (Fig. 3). In the eastern wall of the chancel there was normally the typical Cistercian group of three windows (Kennerstedt 1990:120). Sigurd Curman, in his dissertation of 1912, has constructed a typical older (i.e. twelfth and thirteenth century) Cistercian church plan from his survey of 140 Cistercian churches in Europe (Curman 1912:38). Figure 4 shows Curman's reconstruction of the outlines of a typical Cistercian church. Curman does not treat the churches related to nunneries in his work, with the argument that the parish churches (or, as in Vreta: the royal manor church - author's remark) they took over were of another elderly design (Curman 1912:29-30). In spite of this, I have taken the perhaps controversial standpoint that it is still possible to use his reconstruction for an analysis of nunneries as well. In my opinion Curman neglects the fact that the churches 


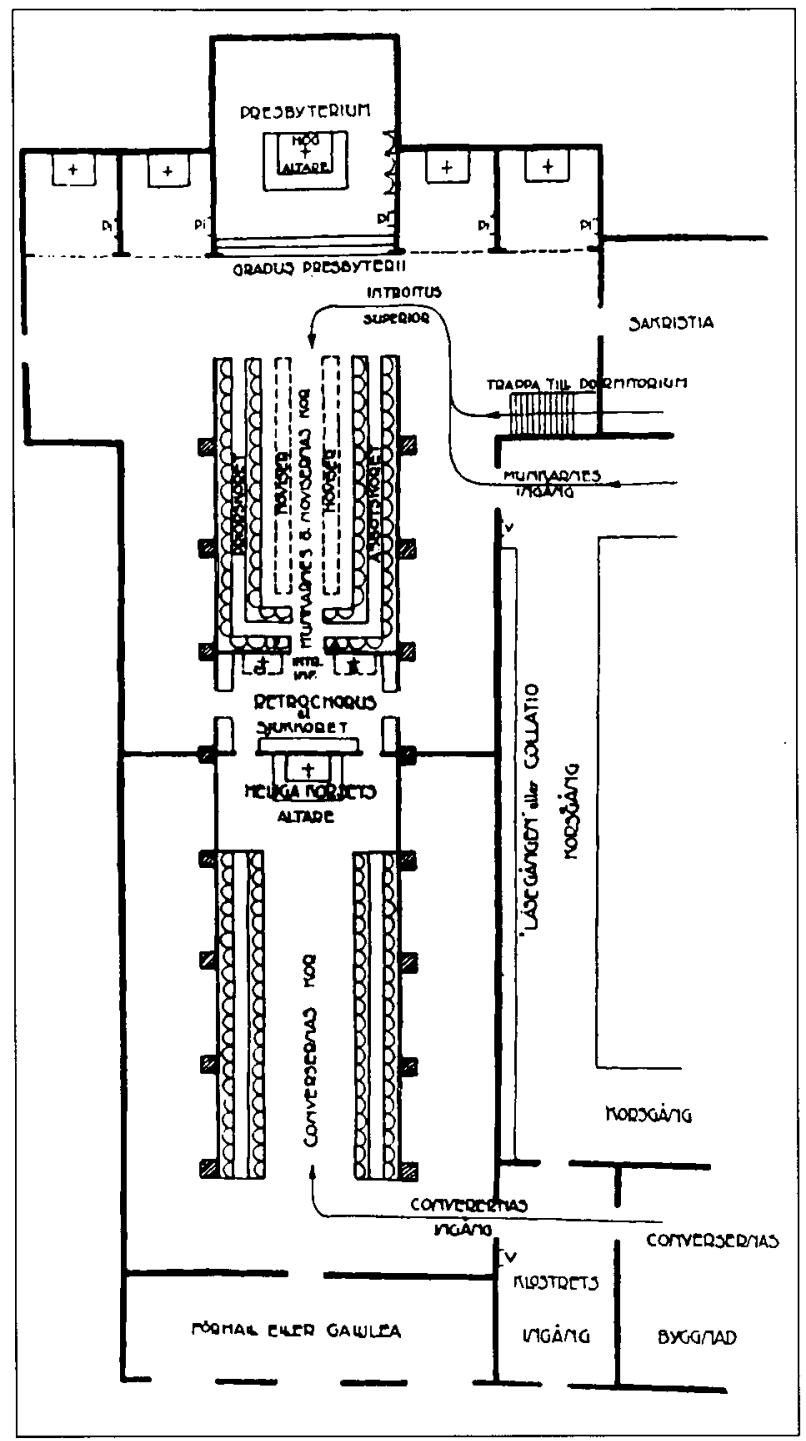

Fig. 4. The plan and division of a typical Cistercian church from the twelfth and thirteenth centuries. $M=$ the image and altar of the Virgin Mary: $B=$ the image and altar of St. Bernard. $P=$ the place prescribed for the Prior. $A=$ the place prescribed for the Abbot. (Curman 1912:38).

choir for the nuns/monks, with the novices placed in the middle, surrounded by the real nuns/monks. The Abbess/Abbot and the Prioress/ Prior were placed at the boundary of this choir, marked by a barrier of stone or wood. On the other side of this barrier were two altars, one for the Virgin Mary (behind the Prior), and one for St. Bernhard (behind the Abbot), the founder of Cistercian order. This location of the image of Mary is considered reliable also by the art historian $\AA$ ke Nisbeth (oral information, Visby 1992-09-24). The choir of Mary and St. Bernhard was called Retrochorus, and here the old and sick nuns/monks were situated, separated from the healthy ones by the barrier. Behind the Retrochorus a main barrier was constructed in order to separate the entire church into two. West of the barrier the church was intended for the conversae/conversi, and if the church

actually were "styled" to fit in with the Cistercian tradition (see, for instance, the plan of Vreta nunnery, Fig. 5, where an older church has been adjusted to the Cistercian "taste", although the west tower remained).

The eastern part of the church began with the presbytery where the main altar was situated (see Fig. 4). This part of the church was elevated from the rest of the church by three steps, and only officiating priests were allowed to be here. West of the presbytery was the functioned as a parish church for laymen, an additional altar was situated here. The offices held at the main altar were for nuns/monks only. In monastery-churches, laymen were initially not allowed to enter, and later on only men were permitted. According to Curman, women could visit a new built church during the first nine days after its consecration (Curman 1912:43); in my opinion, this was probably because it would have been impossible to deny the female donators and wives of 
prominent men admission to the consecration ceremony of the church. It is interesting to note that the symbols of religious identification on the altars are different. The main altar had only a simple cross (Åke Nisbeth, oral information, Visby 1992-09-24), while the old and sick nuns/monks had the Virgin Mary and Bernhard, and the conversae/conversi had the dying Christ on a cross over their altar (Curman 1912:36-43).

In an ideological analysis of the plan of the church, it is important to bear in mind that the church is built up around a channel for direct contact with the divine, for communication with God, which is activated by the religious rituals. All activity in the church is related to that channel - the altar. By means of the altar the divine power is believed to be transmitted from God to humanity through the hands of the priest. The altar can be seen as the focus of heaven and earth, as a meeting place between God and humanity that can only be touched by the priest, a chosen initiated male dressed in ceremonial outfit. The church was divided into two by means of stone and wood barriers - the department for nuns/ monks and the laymens church. In each of them there was an altar, with additional barriers to signify the hierarchy that separated different social groupings within the two churches; the orientation extended from the altars, effectively providing for the intentions of the order.

The sanctuary floor was elevated in three steps over the rest of the floor in the church. In exercising the rituals in the church, the priests literally stepped up from the rest of the assembly, nuns and monks included, and were dressed in a divergent fashion in order to become "other", a chosen, unlike the rest. The prescribed placements of the assembly were strictly oriented from the altars, according to a social hierarchy of space. The more sacred, the more noble, the closer the placement to the altar. It is interesting to observe that the Abbess/Abbot and the Prioress/Prior were placed "on the boundary" of the nuns'/monks' choir and Retrochorus, with Mary and Bernard at their backs (see Fig. 4). In my view this can be seen as an expression of their roles as protectors, mothers/fathers of the monastic community, while the location of the old and sick nuns/monks - excluded from the community by barriers - must be seen as hierarchically stipulated.

The Roman Catholic priests were and still are men. If we study the plan of the church (Fig. 4), we see that the area around the altar is permitted only for a special category of men - the priests. In a monastery, sex - that is a certain design of the human body - is not an obstacle to setting one's foot in that specific area, but rather social position, opportunity to education, relations to potentates in society, etc. In nunneries, sex is the main barrier that denies a nun direct contact with the divine. A woman can never obtain direct contact with God, to touch God as the male priest is able to do with his very hands. In this way the gender ideology - the socio-cultural interpretation of the biological difference between the bodies of women and men - is constructed, embodied, and literally founded in the very church building. Through the daily rituals in church the ideology was acted out in people's lives. The outline of the church make the assumption plausible that God was incarnated as a male, and only males are considered pure enough to intermediate between the divine and humanity - it was undeniable, written in stone and wood.

What seems at first to be an inexplicable fact, that people in this way cooperate in their own submission, can be seen more clearly in a comparision with Maurice Godelier's analysis of slavery, and the slave's necessary cooperation for the maintaining of the system. Godelier explains this with the notion that it was only through slavery that the slave could be liberated from slavery, that is, by being the perfect slave the possibility of liberation was at hand (Godelier 1986:163-4). It is also necessary to see gender as politics exercised on the body, intertwined with 


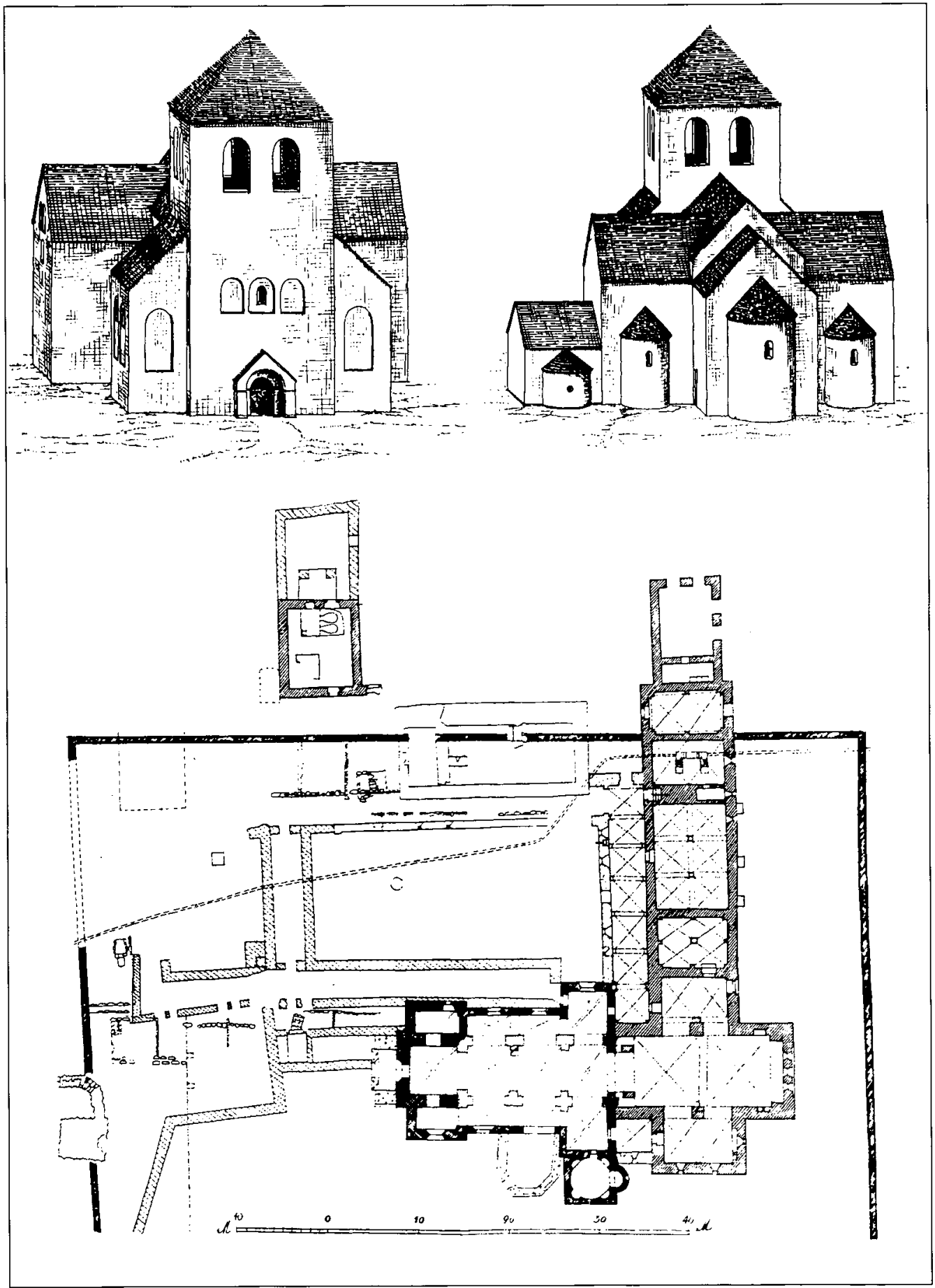

Fig. 5. Vreta church and numnery. Reconstruction of the exterior of the church c. 1150 (before the foundation of the nunnery) seen from west and east. Plan of the nunnery with the church which was rebuilt several times (After Lundberg 1964:17-8, + plan in appendix). 
people's self-image. Since gender is a sociocultural interpretation of the different designs of the bodies of women and men, it functions on the very body of people. The notion of gender is sensed as a part of oneself, and to deny the gender role prescribed by society is a denial of oneself. To this should be added the risk of ex communication from the medieval Church and society if one did not behave properly.

It is interesting to note that an ideological system, which tried by all means to exorcise the human body from its spirit and soul, was so obsessed by that same body that it completely occupied the minds of the women and men consecrated to its denial. The architecture is the very condition for these perpetual exercises in order to obtain control over the body. A monastic life would indeed be impossible in a Scandinavian Bronze Age house $20 \times 8 \mathrm{~m}$ without partition walls, or in open air on the savanna in East Africa!

In practising the rituals in church, in leading daily life, the social order of the abbey was constantly reproduced and recreated. Without the cooperation of each of the nuns/ monks/conversae/conversi/visitors the system would collapse. The church was the centre of the abbey; like the life in the abbey, it was an ideal for people outside it. The exclusiveness of the abbey was dependent on "the world" and the separation from it. It was in church, at the altar, that the transmission of the divine power and grace was acted out, and this was considered essential and of vital importance to all people.

\section{THE SACRED BODY}

An interpretation of the spatial and ritual analysis above shows how the notions concerning gender and the human body are acted out through and made possible by the achitecture of the Cistercian church, and this forms an ideology embodied in the outline of the church. The Cistercian order was dedicated to the Virgin Mary. This means that the
Virgin was considered the ultimate essence of the order. She was the self neglecting woman who by her humble acceptance of the "Immaculate Conception" paid the dept for "the Fall" selfishly caused by Eve. In this way the Virgin Mary is set apart from the human race, because she is not considered stained by the Fall (Warner 1984:254). I would like to argue that the very church building could be seen as a symbol for the Virgin Mary, of her "dehumanized", purified body or even of her "dewomanized" womb, the container of the God-child. The striving for a pure, "dehumanized" body is evident in the simplicity of the architecture - of course, the architecture is simple only compared to the previous Cluny "mode of church production"(!). The striking difference between the Cistercian churches and, for instance, the simple wooden churches of eleventh-century Scandinavia is another matter - the effect on sociey in that case must have been the opposite!

The medieval human body was considered polluted, sinful, and a burden to the woman or man who wanted to live as a true Christian. The only way to God led through the deterioration of the body, by death or selfinflicted pain, illness or other sufferings (Le Goff 1988:84). The body had to be disciplined, punished, and overcome. The only way of obtaining a sacred body was by losing it, a paradox which influenced the entire medieval society. Because of the impossibility of exorcising the body from the true self - the soul - and go on living, it was perfectly natural to elevate Mary - the unhuman human, the bodiless woman - as an ideal for both women and men. It is interesting to observe the attitudes towards the dead human body, and the cult of saints and relics against this background (Le Goff 1988:85). One of the main concerns of the churches seems to have been to take care of the dead bodies of prominent people who were constantly allowed to attend the religious activities in the churches. Just as in life, the wordly social hierarchy decided 
the distance prescribed from the altar. The dead body indeed seems to have been the best body!

The problem for the living was that the body threatened to "take over" again and again, and therefore the utterly complex rituals in order to control it. The rules related to the attitudes toward purity and impurity, body and soul, sleep and vigilance, bodily refuse and food, outside and inside houses, were conditioned by and made possible to act out by the material design of the buildings in which people spent their lives.

The sacred body was an unattainable aim for nuns and monks in the Cistercian abbeys, and still more unattainable for people outside the walls. Yet this illusion - the "debodied" body - was the meaning of life, the ideal and, most importantly, the only way to God. A constant frustration characterized the religious life of the twelfth and thirteenth centuries: the frustration of never being able to obtain what was most desired - the death of all desires.

\section{CONCLUSIONS}

The Cistercians' choice of the Virgin Mary as a symbol for the entire order is of vital importance to an analysis of the ideological dimension of their architecture. Mary, the "debodied" sacred body, the "dewomanized" woman, is the essence of the Cistercian way of life and can be seen as the personified mental dimension of the material practice, i.e. "the Cistercian architecture".

The Cistercian ideology of gender is symbolically personified in the Virgin Mary and materially embodied in the Cistercian church. Through the rituals exercised in the building, the ideology acquired a formative power over the inhabitants/visitors in the abbey, and thereby also a formative power over society as a whole. In order to remain active - activly acted out in peoples lives - and not just dead meaning incapsulated in the architecture, the ideology needed everybody's cooperation.
The ideology of gender is seen as centered around the altar - the focus of heaven and earth. The church was built up around channels of the divine, i.e. the altars in the two churches which were separated by barriers and located within the same walls. The part of the church reserved for nuns/monks and the part reserved for conversae/conversi/laity had strictly regulated rules for placement. Those of high social rank and status had a close position obliged to the altar and thus a close contact with the divine. The most sacred area was reserved for a special category of men who were separated from other people by their special dress and special place in the church. Only these men were allowed to communicate directly with the divine, to literally touch God.

These rules were constantly acted out in the rituals in church and in daily life in the abbey, and they demanded all people's cooperation for their maintenance. The gender ideology and social hierarchy of the Cistercian church was ritualised, recreated and lived through by the activities in it. What appears to be an inexplicable acceptance and cooperation in the subordination of oneself, can be understood in the light of the fact that the specific ideology of gender is absorbed and intertwined with peoples self-image. Since gender is a socio-cultural interpretation of the bodily difference between women and men, the gender ideology - in this case coloured by religious concepts - functions on the very body of people, that is, the notion of gender is conceived of as a part of oneself. To deny one's gender role ascribed by society (religiously or not) is a denial of oneself.

Because of the central importance of the Cistercians in the medieval society throughout the whole of Europe (bearing in mind all the different kinds of societal organisation), their attitudes to and politics exercised on the human body were impossible to ignore. These attitudes and politics were part of an ideological system, the ideology of gender, which had one of its most penetrative 
expressions embodied in the Cistercian church. In fact, this ideology was not abstract and unreachable; it was founded in stone and wood in the very building.

English revised by Laura Wrang.

\section{REFERENCES}

Ambjörnsson, R. \& Elzinga, A. 1987. Tradition och revolution. Huvuddrag $i$ det europeiska tänkandets historia. Stockholm.

Daly, M. 1979. Gyn/Ecology: The Metaethics of Radical Feminism. London.

- 1985. Beyond God the Father: Towards a Philosophy of Womens Liberation. Boston.

Clarke, D.L. 1968. Analytical Archeology. London

Conkey, M. W. \& Spector, J. 1984. Archaeology and the Study of Gender. In: Schiffer, M. (ed.). 1984. Advances in Archaeological Method and Theory vol.7. New York.

Curman, S. 1912. Cistercienserordens byggnadskonst. Kyrkoplanen. Stockholm.

Duby, G. 1980. Le Temps des Cathedrales. L'Art et Societé 980-1420. Paris.

Foucault, M. 1977. Discipline and Punish. London.

Gilchrist, R. 1988. The Spatial Archaeology of Gender Domains: A Case Study of Medieval English Nunneries. Archeological Review from Cambridge 7:1. Cambridge.

Godelier, M. 1988 (1986). The Mental and the Material. London and New York.

Holmström, M. \& Tollin, C. 1990. Alvastra klosters äldre godsinnehav. Framväxt och rumslig struktur samt jämförelser med kontinentala förhållanden. In: Dahlbäck, G. (ed.). I heliga Birgittas trakter. Nitton uppsatser om medeltida samhälle och kultur $i$ Östergötland "västanstång". Uppsala.

Härdelin, A. 1987. Världsflykt och mission. Om munkar, kaniker och predikarbröder i medeltidens kyrka. In Ferm, O. \& Tegnér, G.(ed.). Tanke och tro. Aspekter på medeltidens tankevärld och fromhetsliv. Studier till det medeltida Sverige 3. Stockholm.

Johansson, H. 1987. Gudstjänstliv i Sverige. In:
Ferm, O. \& Tegnér, G.(ed.). Tanke och tro. Aspekter på medeltidens tankevärld och fromhetsliv. Studier till det medeltida Sverige 3. Stockholm.

Kennerstedt, L. 1990. Östgötaslättens romanska kyrkor. In: Dahlbäck, G. (ed.).I heliga Birgittas trakter. Nitton uppsatser om medeltida samhälle och kulturi Östergötland "västanstång". Uppsala.

Kraus, H. 1992 (1982). Eve and Mary: Conflicting Images of Medievial Woman. In: Broude, N. \& Garrard, M.D. 1992 (1982). Feminism and Art History. Questioning the Litany. New York.

Kristeva, J. 1989. Desire in Language. A Semiotic Approach to Literature and Art. Oxford.

Le Goff, J. 1988. The Medieval Imagination. Chicago and London.

Lundberg, E. 1964. Vreta kloster: Stockholm.

McNay, L. 1992. Foucault and Feminism. Cambridge.

Radford Reuther, R. 1989. Mariologi - förtryck eller befrielse? Kvinnovetenskaplig tidskrift 1989 nr 2. Stockholm.

Rey-Henningsen, M. 1986. Det feminina medvetandet i ett kristet samhälle - en mentalitetshistorisk essä om spansk medeltid. Kvinnovetenskaplig tidskrift $1986 \mathrm{nr} 2$. Göteborg.

Sinding-Larsen, S. 1984. Iconography and Ritual. Oslo.

Thompson, S. 1989 (1978). The Problem of the Cistercian Nuns in the Twelfth and Early Thirteenth Centuries. In: Baker,D.(ed.). Medieval Women. Oxford.

Warner, M. 1985. Alone of all her Sex. The Cult of the Virgin Mary. London.

Wolff, J. 1992 (1981). The Social Production of Art. London. 